\title{
„Hand Trauma Zentren - Chancen der Vernetzung“
}

\section{"Chances of a National Hand Trauma Center Network"}

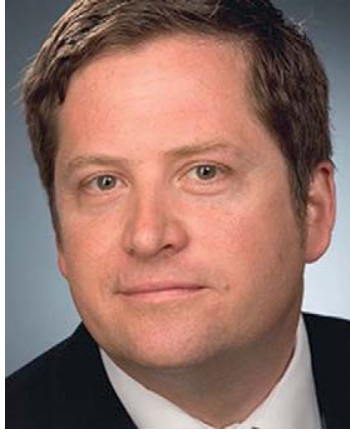

R. E. Giunta
Liebe Leserinnen und Leser,

Die Versorgung von Handverletzungen ist eine Kernkompetenz des Handchirurgen.

Im Vergleich zu anderen europäischen Ländern ist die Bedeutung des Handchirurgen bei der Versorgung von Handverletzungen noch nicht wirklich im Bewusstsein der Öffentlichkeit verankert, sodass Handverletzungen oft nicht primär vom Handchirurgen vorsorgt werden. Die Patientenversorgung hat damit eine erhebliche Chance auf Optimierung durch Ausbau dieser Kernkompetenz. Mit der Fédération Européene des Services d’Urgences de la Main (FESUM) nimmt Frankreich hier eine Vorreiterrolle ein [1]. Bereits auf der Autobahn führen offizielle Verkehrsschilder direkt zum Hand Trauma Zentrum ( $\bullet$ Abb. 1). Auch in anderen Ländern, wie bspw. Italien, wurden bereits Netzwerkstrukturen angelegt [2]

Die Federation of European Societies for Surgery of the Hand (FESSH) hat die Bedeutung auch für die Patientenversorgung und die Entwicklung des Fachgebiets Handchirurgie frühzeitig erkannt und ein Hand Trauma Comittee eingerichtet [3], welches dieses Thema seit einigen Jahren bearbeitet. Thierry Dubert aus Paris war hier ein entscheidender Motor. Für Deutschland waren Riccarda Böttcher aus Berlin und Martin Richter aus Bonn die ersten nationalen Delegierten in
Dear readers,

One of the core competencies of the hand surgeon is the treatment of hand injuries. Unlike in other European countries, there is a lack of public awareness about the importance of qualified hand surgery in Germany, resulting in the fact that most often, hand injuries are not primarily treated by a qualified hand surgeon [1]. Therefore, the development of this core competency offers considerable potential for patient care optimization. With the Fédération Européene des Services d'Urgences de la Main (FESUM), France is pioneer in this field. There, even official road signs on the highway indicate the way to the next Hand Trauma Center ( $\bullet$ Fig. 1). Other countries, e.g. Italy, have also established similar network structures [2].

The Federation of European Societies for Surgery of the Hand (FESSH) has recognized the importance for patient care as well as for the development of hand surgery early on. For this reason, a Hand Trauma Committee [3] was established, which has been working on this issue for several years. Thierry Dubert from Paris contributed significantly to the foundation of the committee. The first national delegates for Germany were Riccarda Böttcher from Berlin and Martin Richter from Bonn, followed by Nicole Schmelzer-
Bibliografie

Dol http://dx.doi.org/ 10.1055/s-0033-1361121 Handchir Mikrochir Plast Chir 2013; 45: 315-317

(c) Georg Thieme Verlag KG Stuttgart · New York

ISSN 0722-1819

Korrespondenzadresse

Univ.-Prof. Dr. med. Riccardo E. Giunta

Handchirurgie Plastische Chirurgie und Ästhetische Chirurgie Klinikum der Ludwig-

Maximilians

Universität (LMU) München

Pettenkoferstraße 8a

80336 München

r.giunta@med.uni-muenchen.de
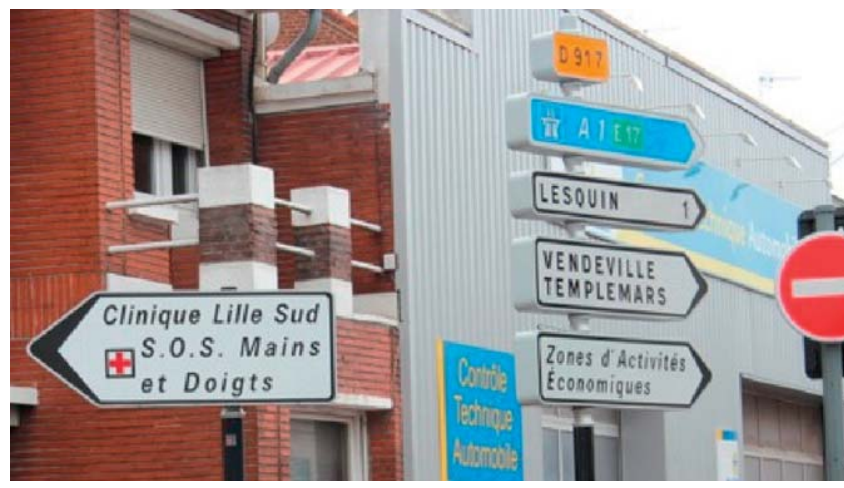

Abb. 1 a, b: Hinweisschilder weisen in Frankreich bereits auf Straßen (a), und Autobahnen (b) zum nächsten Hand Trauma Zentrum hin.

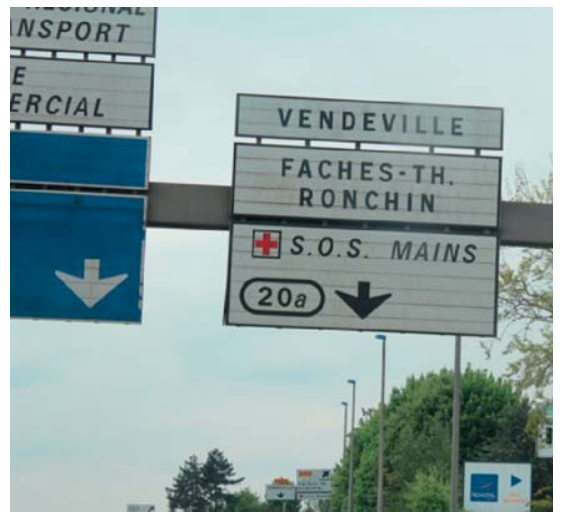


diesem Komitee, gefolgt von Nicole Schmelzer-Schmied aus Bern sowie dem Autor. Durch die Festlegung von Qualitätskriterien für ein Hand Trauma Zentrum nach den Vorstellungen der FESSH und die Einrichtung eines nationalen Validierungsverfahrens wurden einerseits erste Grundlagen für ein Qualitätsmanagement durch den Handchirurgen geschaffen, andererseits auch die Bedeutung des Handchirurgen für die Versorgung von schweren Handverletzungen sichtbar gemacht.

In Deutschland existieren derzeit 26 nach den Kriterien der FESSH validierte Hand Trauma Zentren. 2 wesentliche Chancen ergeben sich aus einer möglichen nationalen Vernetzung:

1. Erstmals könnten durch eine Multicenter Registerstudie landesweite „harte Daten“ zu schweren Handverletzungen gesammelt werden und diese für eine weitere Verbesserung der Versorgung von Handverletzten genutzt werden.

2. Eine Vernetzung der Hand Trauma Zentren könnte auch für die Öffentlichkeitsarbeit der Deutschen Gesellschaft für Handchirurgie (DGH) verwendet werden, um damit das Fach Handchirurgie auch für die Zukunft stärken.

Mit unserem Pilotprojekt in München (www.handverletzung. com) haben wir eine einfache Plattform geschaffen, welche die Chancen einer nationalen Vernetzung zur Optimierung der Patientenversorgung aufzeigen kann. Ein erster Vorschlag für einen Untersuchungsbogen für eine Registerstudie wird in diesem Heft veröffentlicht und steht auf der Webseite der HaMiPla als Download zur Verfügung [4]. Die Ethikkommission der LudwigMaximilians Universität München hat einer solchen Studie zugestimmt. Die Datenerhebung an zunächst 2 Zentren in München wurde bereits gestartet. Gerne kann sich jedes durch die FESSH validierte Hand Trauma Zentrum an diesem Pilotprojekt beteiligen und damit das Projekt stärken.

Das Pilotprojekt wurde zuletzt in der Mitgliederversammlung der DGH und auch auf dem DGH Kongress in Düsseldorf im Oktober vorgestellt. Die DGH wird auf ihrer nächsten Klausurtagung evaluieren, welche Möglichkeiten sich damit ergeben und wie sie am besten verwirklicht werden könnten.

Neben dem Potenzial zur Verbesserung der Patientenversorgung wäre eine Vernetzung ein interessantes Projekt für die DGH, in den nächsten Jahren damit ihr Profil zu schärfen. Die Vernetzung der Hand Trauma Zentrum könnte als Imagekampagne genutzt werden, um das Problembewusstsein in der Öffentlichkeit zu steigern. Kompetente Aufklärung zu den Themen Prävention von Handverletzung [5], häufige Ursachen von Handverletzungen und (Erst-) Versorgung von schweren Handverletzung auf einer professionellen Webseite könnten die Kompetenz des Handchirurgen aufzeigen. Zur Steigerung der „Awareness“ könnte man darüber hinaus, dem Beispiel Frankreichs folgend, einen „National Hand Trauma Prevention Day“ durchführen [6], welcher öffentlichkeitswirksam die Bedeutung des Handchirurgen für die Patientenversorgung herausstellen könnte.

Im vorliegenden Heft haben wir für Sie, liebe Leser, die wichtigsten Entwicklungen zum Thema FESSH Hand Trauma Zentrum und zu den Chancen der Vernetzung zusammengefasst. Wir konnten Autoren aus verschiedenen Ländern Europas dazu gewinnen, den aktuellen Stand darzustellen und damit einen Stimulus für die Weiterentwicklung der Handchirurgie in Deutschland in den nächsten Jahren zu geben. Ich danke allen Autoren für ihre Beiträge und den Gutachtern für die schnelle und kompetente Begutachtung der Manuskripte zur Optimierung im Peer Review Prozess.
Schmied from Bern as well as the author of this article. By defining quality criteria for a Hand Trauma Center in accordance with the FESSH standards as well as by establishing a national accreditation process, for one thing, the groundwork was laid for a quality management performed by the hand surgeon; for another, the importance of having severe hand injuries treated by a qualified hand surgeon was stressed.

Currently, 26 Hand Trauma Centers accredited according to the FESSH standards exist in Germany. A national network of such Hand Trauma Centers might offer the following chances:

1. For the first time, "hard data" related to severe hand injuries could be collected on a national scale via a multicenter register study and be used for further optimizing hand injury care.

2. The Deutsche Gesellschaft für Handchirurgie (German Association for Hand Surgery, DGH) could also use such a Hand Trauma Center network for public relation purposes and thus, strengthen the medical field of hand surgery in the future.

Our pilot project in Munich (www.handverletzung.com) offers a structured platform and clearly shows the chances of a national Hand Trauma Center network for patient care optimization. A first suggestion for an examination form to be used in a register study is published in this issue and available for download on the HaMiPla website [4]. The ethics commission of the LMU Munich has given approval for such a study. Data collection at 2 centers in Munich has already begun. Each Hand Trauma Center accredited by the FESSH is invited to participate in this pilot project.

The pilot project was presented recently at the DGH General Meeting as well as the DGH Congress in Düsseldorf in October. On the occasion of the next retreat, the DGH will evaluate which are the chances of this project and how the same can be optimally used.

In addition to the potential of improving patient care, the establishment of a network would also be interesting because it would allow the DGH to sharpen its profile in the next years. A network of several Hand Trauma Centers could serve as an image campaign for increasing public awareness. Competent information related to hand injury prevention [5], common causes for hand injury and (primary) care of severe hand injuries presented on a professional website would clearly show the competence of the hand surgeon. For raising the awareness even more, a "National Hand Trauma Prevention Day" could be established [6], as it also exists in France, in order to draw public attention to the importance of qualified hand surgery for patient care.

In the present issue, we have summarized for you the most important developments related to FESSH Hand Trauma Centers and the chances such network structures might offer. We were able to motivate authors from different European countries to give an overview of the current status and thus, contribute to stimulate the development of hand surgery in Germany during the next years. I would like to thank all authors for their articles and the reviewers for their fast and competent review of the manuscripts within the peer review process.

Furthermore, after a very long break, this issue includes again the section "Mitteilungen aus den Fachgesellschaften" ("News from the Society"). The Deutsche Gesellschaft für Handchirurgie (DGH) is planning to Inform the readers about the Annual Congress on a regular basis, as well as to present other relevant news, such as the DGH newsletter. For the present issue, the current managing board of the DGH has appointed Caroline Dereskewitz from Hamburg to report on the DGH Congress, which took place in Düsseldorf from October 12-14th 2013 under the 
Nach einer sehr langen Pausen erscheinen in dieser Ausgabe wieder „Mitteilungen aus den Fachgesellschaften“. Die Deutsche Gesellschaft für Handchirurgie (DGH) plant hier in regelmäßigen Abständen vom Jahreskongress zu berichten und auch andere Mitteilungen wie z.B. die Newsletter der DGH zu präsentieren. In dieser Ausgabe berichtet Caroline Dereskewitz aus Hamburg im Auftrag des derzeitigen Vorstands vom DGH Kongress in Düsseldorf, der dieses Jahr vom 12. bis 14. Oktober unter der Leitung von Joachim Windolf in Düsseldorf stattgefunden hat.

Die Handchirurgie Mikrochirurgie Plastische Chirurgie nimmt als offizielles Organ der DGH sehr gerne diese neue Rubrik mit auf.

Schließen möchte ich mit folgendem Satz, der die wesentlichen Aspekte dieses Schwerpunktheftes für eine optimierte Patientenversorgung und eine positive Wahrnehmung der Handchirurgie in der Öffentlichkeit zusammenfasst:

\section{„Mit einer Handverletzung gehe ich zum Handchirurgen, mit} einer Augenverletzung gehe ich ja auch zum Augenarzt.“

München im November 2013

Riccardo Giunta

\section{Danksagung}

Frau Dr. Elisabeth Haas sei für die Bereitstellung, der im Rahmen ihres FESSH Reisestipendiums bei Philippe Bellemere, entstandenen Abbildungen gedankt.

\footnotetext{
Literatur

1 Dubert T. The French initiated FESUM - Historical development, experiences and perspectives. Handchir Mikrochir Plast Chir 2013; 45: 323-325

2 Pajardi G. The Italian CUMI. Handchir Mikrochir Plast Chir 2013; 45: 332-334

3 Battiston B, LetiAcciaro A, DeLeo A. The Role of the FESSH Hand Trauma Committee in Europe. Handchir Mikrochir Plast Chir 2013; 45: 326-331

4 Haas E, Volkmer E, Holzbach $T$ et al. Über Versorgungsstrukturen und Möglichkeiten der Optimierung durch Vernetzung bei schweren Handverletzungen und Replantationen. Handchir Mikrochir Plast Chir 2013; 45: 318-322

5 Leixnering M, Quadlbauer S, Szolarz C et al. Prävention von Handverletzungen - Aktueller Stand in Europa. Handchir Mikrochir Plast Chir 2013; 45: 339-343

6 Bellemerre P. Experiences of a national campaign for hand trauma prevention in France. Handchir Mikrochir Plast Chir 2013; 45: 335-338
}

direction of Joachim Windolf. As the official organ of the DGH, the journal Handchirurgie Mikrochirugie Plastische Chirurgie is pleased to introduce this new section.

Let me close with a statement that summarizes the most important aspects of this special issue and its topics of patient care optimization and establishment of a positive image of hand surgery in the public:

"In the same way as I am going to see an ophthalmologist in the case of eye injury, I am going to see a hand surgeon in the case of hand injury."

Munich, November 2013 Riccardo Giunta 